Prof.dr.sc. Sulejman KENDIĆ, spec. ginekologije i opstetricije ${ }^{1}$

Prof.dr.sc. Adem Salihagić, spec. oralne kirurgije ${ }^{2}$

\title{
LIJEČNIČKE GREŠKE / POGREŠKE - DEFINICIJE, UZROCI I ODGOVORNOSTI LIJEČNIKA
}

\section{Sažetak}

Predmet medicinske/zdravstvene djelatnosti jeste očuvanje, zaštita života $i$ unapredenje zdravlja pojedinaca $i$ drustva kao temeljnih vrijednosti. Od medicinske profesije se zahtijeva da se kao životno usmjerenje prihvati prosvjećenosti zastiti ljudskog zdravlja, da se poštuje ljudski život, ljudske vrijednosti i dostojanstvo, da se uvijek u prvi plan stavlja dobrobit pacijenta, da se svjesno preuzima odgovornost za pacijenta, da se pomoć pruža uvijek jednako svima i po savjesti. Štete koje nastanu u obavljanju ove djelatnosti čine se posebno značajnim i pitanje odgovornosti je posebno osjetljivo. Medicinska djelatnost osim što je regulirana pravilima struke, bila je regulirana oduvijek etičkim normama, a tek periferno pravnim pravilima. Doktor-pacijent je do sredine XX vijeka bio reguliran više moralnim nego pravnim normama, dok se danas situacija značajno izmijenila.

Medicina kao nauka $i$ kao praksa doživljava brzi naučni $i$ tehnološki napredak. Povećava se broj intervencija $i$ zdravstvenih usluga. Zahtjevi korisnika su složeniji, intervencije ofenzivnije, gdje se uključuje veliki broj različitih stručnjaka $u$ sistem zaštite, a time $i$ rastu veće mogućnosti za nastanak grě̌aka i nanošenja štete pacijentu.

Ključne riječi: liječničke greške, stručne greške, komplikacije, omaška.

\section{Uvod}

Pojam liječničke greške/pogreške pojavio se u literaturi sredinom XIX. stoljeća. Pojam liječnička greška potječe iz medicine, a ne iz prava. Njen

\footnotetext{
${ }^{1}$ Visoka zdravstvena škola u Bihaću

${ }^{2}$ Pedagoški fakultet u Bihaću - Odsjek za sport
} 
je tvorac poznati patolog Rudolf Virchow koji je pod pojmom stručna greška liječnika podrazumijevao kao «Kršenje opće priznatih pravila umijeća liječenja zbog pomanjkanja dužne pažnje ili opreza".

Medicinski gledano liječničke pogreške se mogu podijeliti u odnosu na kliničke faze u kojoj se događa rad. Pogreške mogu biti: dijagnostičke, terapijske, preventivne i liječničke pogreške zbog loše komunikacije. Neki autori ih dijele i na stručne pogreške, pogreške pravila i pogreške iz neznanja.

\subsection{Liječničke pogreške/greške, definicije}

Pojam "medicinske greške" ili "greške u tretmanu" obuhvaća sve greške u: profilaksi, dijagnostici, liječenju i zdravstvenoj njezi, ako se medicinski postupak (zahvat) nije do kraja na planirani način izveo, a u tom postupku izvođenja nastupi šteta za bolesnikovo zdravlje. U medicinske pogreške/greške spadaju: nemar-nehaj, neadekvatna primjena lijeka, neispravna ili nestručna upotreba opreme/instrumentarija. Greška u tretmanu nastaje zbog zanemarivanja ili odstupanja od medicinskog standarda, odnosno medicinske nauke, postupak koji je izveden bez dužne pažnje.

"Stručna greška liječnika je kršenje opšte priznatih pravila umijeća liječenja zbog pomanjkanja dužne pažnje ili opreza”. Radi se o tzv. iskrivljenom postupanju contra legem artis. Stručna greška je svako nepridržavanje opće utvrđenih načela medicinske struke ili operativne tehnike koja najuspješnije rješava "slučaj".

Komplikacije i medicinska (liječnička, stručna) greška su sadržajno razgraničene. Komplikaciju i medicinsku grešku ne treba smatrati kao obligatne zavisne varijable.

"Komplikacija" nastaje bez obzira na medicinski ispravan i stručno sproveden postupak, koji je izveden pravilnom upotrebom ispravne medicinske opreme i sredstava uz optimalnu organizaciju rada. Komplikacija je sudbinski tok bolesti. Komplikacije nastaju primjenom kliničkih postupaka s kojim se rješava stanje. Komplikacije su incident kod invazivnih postupaka (hiruški zahvati i dr. dijagnostički postupci). 
"Omaške" su pogrešne liječničke radnje uslovljene nesavršenošću nauke i čovjekovom nedovoljnošću. Greška u proceduri se tretira kao omaška.

"Nesretni slučaj u medicini" je svaki nepovoljni ishod liječenja koji nije izazvan greškom liječnika nego slučajnostima ili nepovoljnim sticajem okolnosti koje na temelju medicinskih saznanja nije bilo moguće predvidjeti.

Krivnja zdravstvenog radnika jedna je od ključnih pretpostavki odgovornosti.

Dvije su vrste krivnje:

1. namjera

2. nepažnja : obična nepažnja (culpa levis) i krajnja nepažnja (culpa lata)

\subsubsection{Vrsta medicinskih greški/pogrešaka}

Medicinska pogreška je širok-rastezljiv pojam.

U praksi to je: "Oni koji rade u medicinskoj struci imaju obvezu brige prema pacijentima. To jednostavno znači da medicinska struka mora osigurati da pacijenti dobiju prikladno liječenje na odgovarajući način. $U$ većini slučajeva liječnici obavljaju svoj posao na visokoj razini. Međutim, ponekad se greške događaju i zbog tih greški, pacijenti su ti koji plaćaju visoku cijenu svojim narušenim zdravljem, a nažalost ponekad i svojim životom. Nemar i nesavjesno liječenje od strane liječnika može stvoriti kod pacijenta mnoge posljedice i financijske troškove prouzrokujući trajnu štetu"!

Medicinska nepažnja ili nemarnost, širok je pojam koji obuhvaća niz različitih medicinskih pogrešaka i nekvalitetan pristup u liječenju. U praksi to može značiti:

- Pogrešne dijagnoze ili kašnjenje u dijagnozi, što dovodi do komplikacija ili pogoršanja stanja pacijenta;

- Hirurške pogreške koje uzrokuju nepotrebnu bol ili defekte; 
- Zanemarivanje ili nedostatak liječenja, što dovodi do pogoršanja zdravstvenog stanja pacijenta;

- Komplikacije i nuspojave uzrokovane propisivanjem pogrešnih "neadekvatnih-bespotrebnih" lijekova (uključujući i anestetike);

- Ozljede majke ili djeteta tokom poroda (smrtnim ishoda po majku ili dijete)

Reason $^{3}$ stručnjak fenomena ljudskih pogreška, predložio je razlikovanje sljedećih vrsta pogrešaka:

1. Latentne (počinjene zbog nedostatka sistema u kojem se djelatnost obavlja).

2. Aktivne tj. one koji su zaposlenici učinili lično, a klasificiraju se kao:

- $\quad$ slip (pogreška zbog nepažnje)

- lapsus (pogreška zbog zaborava)

- mistake i vilation (pogreške koje su u skladu sa namjerama koje su ih uzrokovale)

Sumarno pogreške zdravstvenih radnika su trojake i to:

1. Nepridržavanje utvrđenih naučnih spoznaja i pravila profesionalne tehnike ("Vitium artis").

2. Povreda načela humanosti specifično za medicinsko zvanje.

3. Banalne nesmotrenosti i nemarnosti. ${ }^{4}$

Liječničke pogreške su u porastu. Statistike SAD-Institut za medicinu navode, a objavljuju se u tiskanim medijima: $44 \%$ tehničke pogreške, 17 \% pogrešne dijagnoze, $12 \%$ propust koji rezultira ozljedom i $10 \%$ kriva terapija, loš uređaj. Liječničke pogreške se javljaju (po izvještaju Reasona

\footnotetext{
${ }^{3}$ Reason, J. De Lval, M,. Human errors:models and management, BMJ (2001), 320:768770

${ }^{4}$ Mašić I., Novo A. Patient,s rights and medical data protection in B\&H. AIM, 2005 (13)97-9.
} 
): u $8 \%$ bolnica, $22 \%$ ordinacija, $7 \%$ operacijska sala, $5 \%$ klinika, $5 \%$ hitna služba, $4 \%$ apoteka, $3 \%$ vlastiti dom, $1 \%$ laboratorij, $1 \%$ organizirani smještaj. ${ }^{5}$

\subsubsection{Uzroci liječničkih pogrešaka/greški}

\section{Najčešći uzroci liječničkih greški/pogrešaka nastaju:}

- naglim uvođenjem moderne tehnologije u medicinu i neadekvatna edukacija i stjecanje vještina za rad,

- uvođenjem šireg dijapazona složenih interventnih usluga (visoko sofisticirani zahvati), preopterećenost na poslu

- propusti u organizaciji rada u višem sistemu i podsistemima,

- nedostatna u sistemu komunikacije izmedu pojedinih dijelova ustanove ili pojedinih medicinskih/zdravstvenih radnika,

- neispravnost i nedovoljna stručna upotreba medicinskih aparata i tehnoloških pomagala,

- depersonalizacija pacijenta u odnosu pacijent-doktor, gdje pacijent postaje broj, a ne osoba,

- kršenje pravila struke, nedostatka pažnje, nemarnost, izostanak potrebne intervencije,

- nepoštivanje odgovarajućih terapijskih ili dijagnostičkih postupaka,

- nedovoljna klinička osposobljenost liječnika i loša komunikacija doktor-pacijent,

- natjecanje dvaju ili više doktora s ciljem dokazivanja superiornosti,

- gubitak povjerenja u ljekare i jačanje trenda pravne regulacije odnosa koji su nekad bili regulirani moralnim normama, sada postoje ugovoreni strogo poslovni odnos pacijent-doktor, pa su tužbe češće.

\footnotetext{
${ }^{5}$ http://www.novilist.hr/Zivot-i-stil/
} 
Uzroci pogrešaka mogu biti posredni i neposredni.

U posredne uzroke ubrajaju se:

- nedostatak ili zloupotreba sredstava,

- loša organizacija rada,

- preopterećenje u radu.

Neposredni uzroci pogrešaka mogu biti u:

- propustima u komunikaciji

- tehnici ili tehnologiji,

- znanju,

- tehničkim znanjima i sposobnostima

- nadzoru sistema

Pogreške, direktno vezane za zaposlenika su nezainteresiranost za posao, nemar, fizičke ili mentalne smetnje, alkoholizam i ovisnost o drogama.

Nesavjesno liječenje čine samo one liječničke pogreške koje proizlaze iz liječnikova nesavjesnog postupanja, dakle koje su posljedica povrede standarda dužne pažnje ili nedostatka potrebnih znanja i vještina. Liječničke greške su ili tehničke prirode (pogrešna dijagnoza ili tretman) ili se pak sastoje u nepoštivanju prava pacijenata (najčešće se to odnosi na povredu prava informiranog pristanka ili pak povredu liječničke tajne). ${ }^{6}$

Nesavjesno liječenje bolesnika sastoji se od dvije komponente:

a. Liječnikovo djelovanje odnosno nedjelovanje (primjena očito neprikladnog sredstva ili očito neprikladnog načina liječenja, neprimjenjivanje odgovarajucih higijenskih mjera, uopće nesavjesno postupanje).

${ }^{6}$ European Committee on Legal Co-operation, Report on Medical Liability in Council of Europe Member States - A Comparative study and Recommendations (by Herman Nys), CDCJ (2005) 3, Strasbourg, 21 March 2005. 
b. Štetne posljedice koje nastaju za bolesnika (pogoršanje bolesti, narušenje zdravstvenog stanja bolesnika).

Česte su pogreške u intenzivnim njegama, gdje se pacijentima često daju pogrešni lijekovi i to prije svega zbog nedostatka komunikacije između doktora i medicinskih sestara, stresa i umora.

\section{Odgovornosti liječnika za učinjenu "liječničku pogrešku/grešku}

Za liječničke pogreške/greške mogu slijediti četiri vrste odgovornosti:

2.1. Moralno etička odgovornost (koju uglavnom sankcioniraju stručne udruge/udruženja ukoliko se radi o povredi kodeksa etike i medicinske deontologije, a najteža sankcija je obično gubitak licence za obavljanje određenog posla). Medicinska deontologija je širi pojam od medicinske etike, jer se medicinska deontologija bavi definiranjem i izučavanjem dužnosti (i prava) pripadnika profesije, što znači da naglasak stavlja ne samo na etičko nego i na pravnu dimenziju odnosa.

2.2. Gradansko-pravna (odgovornost u obliku naknade štete za individualne greške koje dovode do povrede pacijenta). Za dobijanje odštetnog zahtjeva važno je utvrditi krivnju i standard dužne pažnje liječnika, uzročnu vezu između radnje odnosno propusta liječnika i nastale posljedice te nastalu štetu. Liječnik se ne može osloboditi građanskopravne odgovornosti navodom da je loše obrazovan, da nema dovoljno iskustva ili da nije mogao pratiti napredak u svojoj struci. U brojnim pravnim sistemima kao standard dužne pažnje uzima se pažnja savjesnog i razumnog liječnika iste specijalizacije $\mathrm{u}$ istim ili sličnim uvjetima. ${ }^{7} \mathrm{U}$ Engleskoj se pak standardom dužne pažnje smatra praksa koju prihvata kao dobra liječnička profesija ili sudovi (tzv. Bolam test). ${ }^{8}$ Odgovornost je isključena ukoliko se liječnik ponaša u skladu s ustaljenom liječničkom praksom, ali uvijek postoji mogućnost za pacijenta da može dokazati da određena ustaljena praksa nije primijenjena savjesno. U nekim pak

\footnotetext{
${ }^{7}$ Georg J. Annas, The Rights of Patients, 341, 343-34 (3. izd., 2004).

${ }^{8}$ M.A. Jones, Medical Negligence 95 (1996) te J. V. McHale, Medical Malpractice in England-Current Trends, 1 European Journal of Health Law, 135, 136-39 (2003).
} 
državama standard dužne pažnje je određen znanjem, sposobnošću i pažnjom iskusnog liječnika u određenom području (specijalizaciji). Od liječnika se traži da prati i savladava nove metode liječenja, a standard se određuje prema stanju znanstvenih spoznaja u vrijeme liječenja. Od liječnika se zahtjeva da postupa s povećanom pažnjom, prema pravilima struke i običajima (pažnjom dobrog stručnjaka). Kad liječnik ne postupa s pažnjom dobrog stručnjaka, radi se o običnoj nepažnji (culpa levis), a ako ne postupi ni onako kako bi postupio svaki prosječan liječnik radi se o gruboj nepažnji (culpa lata) koja predstavlja viši stepen krivnje. ${ }^{9}$

Utvrđivanje uzročne veze važno je kako bi se utvrdilo postoji li odgovornost liječnika kao i da bi se utvrdilo za koje štetne posljedice liječnik treba odgovarati. Pitanje uzročne veze između štetne radnje liječnika kao uzroka i nastale štete kao posljedice rješava se uglavnom ili primjenom teorije ekvivalencije (jednake vrijednosti svih uzroka) ili pak teorije adekvatnosti (tipičnog uzroka). Teorija ekvivalencije smatra uzročnom sve ljudske radnje koje su na bilo koji način utjecale na nastanak posljedice. Ne pravi razliku između bitnih i nebitnih, izravnih i neizravnih, bližih i daljih uzroka. Ova teorija se obično izražava kroz formulu „but for test" ili „conditio sine qua non“ (šteta ne bi nastupila da se liječnik nije ponašao nesavjesno). Prema toj formuli uzročnost se utvrđuje hipotetičkim postupkom eliminacije - u mislima (hipotetički) se isključi (eliminira) liječnikova radnja i pita se da li bi i bez nje nastupila posljedica. Ako bi nastupila, uzročnosti nema, ako ne bi nastupila, uzročnost ipak postoji. Dakle, ukoliko je liječnik postavio pogrešnu dijagnozu, ali ni tačna dijagnoza ne bi dovela do drugačijeg tretmana, onda nema odgovornosti liječnika. ${ }^{10}$

Propust liječnika smatrat će se uzročnim ukoliko se šteta može razumno pripisati povredi dužne pažnje. Dakle veza između radnje i štetne

\footnotetext{
${ }^{9}$ Martin Vedriš, Petar Klarić, Građansko pravo 560/61 (2003).

${ }^{10}$ Steffan Callens, Medical Civil Liability in Belgium. Four Selected Cases, 1 European Journal of Health Law, 115, 120-24 (2003). 115, ), Robert S. Toth, Medical malpractice: physician as defendant, in Legal Medicine - Legal Dynamics of Medical Encounters 48283 (1988).
} 
posljedice ne mora se dokazati sa sigurnošću, ali uvijek treba pokazati o kojem stepenu vjerojatnosti se radi da je neki uzrok doveo do neke posljedice. Ako djeluje više uzroka kao uzrok uzima se onaj koji je štetnoj posljedici najbliži i za njeno nastajanje najtipičniji. U Austriji, ukoliko se ne može dokazati koji uzrok prevladava primjenjuje se institut $t z v$. podijeljene odgovornosti izmedu liječnika i pacijenta. ${ }^{11}$ Neki pravni sistemi primjenjuju i tzv. teoriju izgubljene šanse prema kojoj valja nadoknaditi ne samo stvarno pretrpljenu štetu, već i gubitak šanse da se izliječi ili preživi. $^{12}$

Teret dokaza u velikom broju pravnih sistema leži na pacijentu. Pacijent mora dokazati uzročnu vezu između liječnikove radnje odnosno propusta i štete, ali i liječnikovu krivnju (da se liječnik nije ponašao sa dužnom pažnjom odnosno da nije postigao određen rezultat koji je obećao), dok razloge isključenja protupravnosti i krivnje treba dokazati sam liječnik. Pacijentima se pokušava na različite načine olakšati teret dokaza pa se tako $\mathrm{u}$ nekim pravnim sistemima presumira krivnja kod velikih ili organizacijskih pogrešaka i tako se teret dokaza prebacuje na liječnika, odnosno zdravstvenu ustanovu. U nekim pravnim sistemima je teret dokaza u potpunosti prebačen na liječnike i zdravstvene ustanove. No, liječnik odnosno zdravstvena ustanova su ti koji moraju dokazati da su prilikom pružanja zdravstvene usluge postupali lege artis.

Što se tiče štete svi pravni sistemi priznaju naknadu materijalne ili imovinske, te nematerijalne štete (pretrpljena duševna ili fizička bol odnosno strah). Da bi počelo popravljanje nastale štete, moraju se kumulativno ispuniti sljedeće pretpostavke:

\footnotetext{
11 Jos Dute, Medical Malpractice Liability: No Easy Solutions, 1 European Journal of Health Law 85, 87 (2003).

12 B.A. Koch, Alternatives to Full Proof of Causation, An Overview for the Biomedical Research Scenario, in Evalutie Tijdelijek besluit verplichte veryekering bij medischwetenschappeelijekonderzoekmet mensen 247-252 (J.C.J. Dute i M.G. Faure, eds., 2002. Miquel Martín-Casalas, Jordi Ribot Igualda i Josep Solé Feliu, Medical Malpractice Libility in Spain: Cases Trends and Developments, 1 European Journal of Health Law 153, 159-63 (2003).
} 
1. Subjekti odnosa odgovornosti za štetu

2. Štetna radnja

3. Šteta

4. Uzročna veza

5. Protupravnost

Štetnik može biti:

a) Zdravstvena ustanova odnosno njezin vlasnik; moguća je i paralelna odgovornost zdravstvene ustanove, te liječnika zaposlenog u njoj, ali samo za slučaj da je štetu počinio namjerno

b) Zdravstveni radnik privatne prakse - odgovara i za svoje uposlenike, te pomoćnike

\section{Oštećenik može biti:}

a) pacijent lično ili

b) članovi njegove uže obitelji (bračni drug, djeca, roditelji), te braća i sestre ili izvanbračni drug, ako su s njim bili u trajnijoj zajednici života ali samo u slučaju da je pacijent umro.

2.3. Prekršajna (obično novčana kazna za neke manje povrede).

2.4. Kaznena (tamo gdje je kroz zaštitu individualnog interesa potrebno zaštititi širi društveni interes). Ovdje spadaju:

- nesavjesno liječenje,

- samovoljno liječenje,

- izvođenje kriminalnih abortusa i eutanazije

- nedozvoljeno presađivanje dijelova ljudskog tijela,

- proizvodnja i prodaja štetnih sredstava za liječenje,

- nepružanje medicinske pomoći.

Kaznenopravna odgovornost liječnika znatno je rjeđa u praksi od građanskopravne. Temeljna razlika između ova dva tipa odgovornosti je u 
standardu dužne pažnje kojeg liječnik treba povrijediti da bi uslijedila odgovornost (kaznena odgovornost obično slijedi samo za grubu nepažnju) ${ }^{13}$ te cilju koji se želi postići ovim tipovima odgovornosti (dok je građanskoj odgovornosti liječnika glavni cilj nadoknaditi štetu žrtvi, glavni cilj kaznene odgovornosti je zaštita interesa društva i odgojna funkcija samog kaznenog postupka i presude putem kojih se nastoje učvrstiti određene moralne i društvene vrijednosti).

Jedan od razloga isključenja odgovornosti je tzv. nesretni slučaj ili «sudbinski tok bolesti». U biti je riječ o slučaju i slučajnim štetama na području odgovornosti za štetu u medicini. Općenito se slučajem naziva događaj koji se ne može nikome pripisati u krivnju. U medicini se njime označava odsutnost liječničke greške i uzročne veze. Postoji onda kada se štetna posljedica nije mogla savladati, uprkos tome što je liječnik postupao $s$ potrebnom pažnjom.

\section{Kad se pogreška desi šta treba poduzeti?}

- da se pogreška na najbolji način razumije,

- objektivno i nepristrano procijeniti uzroke i posljedice,

- naučiti se upravljati sa posljedicama pogrešaka,

- preuzeti odgovornost za pogrešku,

- dobra komunikacija s pacijentom, njegovom obitelji i medijima

- definirati promjene i dopune trajne profesionalne edukacije

\section{Zaključak}

- Dolazi do povećanja i širenja krize liječničke odgovornosti.

- Izvršiti reformu zdravstvenog sistema u kojem će biti održiv sistem liječničke odgovornosti koji će pružiti zaštitu pacijentima od

\footnotetext{
${ }^{13}$ Ukoliko je postojao značajan i neopravdan rizik da će po pacijenta uslijed liječničkog zahvata ili propusta nastupiti štetna posljedica te ukoliko je liječnik trebao predvidjeti takav rizik, a to što ga nije predvidio predstavlja značajno odstupanje od standarda dužne pažnje.
} 
nesavjesnog postupanja liječnika, ali i zaštiti liječnike od neutemeljenih tužbi.

- Pravljenje razlike između nesavjesnog postupanja i nastupanja štetne posljedice koja nije rezultat povrede standarda dužne pažnje odnosno nedostatka znanja ili sposobnosti i za koju liječnik ne bi smio odgovarati.

- Stvaranja zajedničkog standarda i harmonizacije "dužne pažnje" za cijelu Europu i pristupiti izradi novog protokola uz Konvenciju o ljudskim pravima s kojim su liječnici dužni postupati.

- Upoznati liječnike kroz udruge za činjenje grešaka, a da je kaznena odgovornost liječnika legitiman mehanizam za osiguranje kvalitete liječničkih usluga.

- Utvrđivanje odgovornosti liječnika za pogrešku je jedan od ciljeva prevencija budućih grešaka.

- Raditi na poboljšanju odnosa liječnika i pacijenata kako se pacijenti ne bi osjećali depersonalizirano.

- Obaveza doktora medicine:

- Primjena savremenih medicinskih postupaka i tehnologija,

- Praćenje dostignuća u razvoju medicinske nauke,

- Zabranjeno je ugrožavanje zdravlja ljudi.

- Zdravstvena usluga standardnog kvaliteta podrazumijeva usaglašenost pružene zdravstvene zaštite sa savremenim medicinskim saznanjima, tehnologijom i utvrđenim standardima, u skladu sa pravilima zdravstvenog osiguranja.

- Liječnik odgovara samo kada je njegova medicinska intervencija bila pogrešna i kada je on za to kriv. Krivnja se mora dokazati.

- Redovni profesor na Ekonomskom fakultetu Univerziteta u Sarajevu, Veljko Trivuna (Dipl.pravnik, dr.pravnih nauka), navodi: "U američkim su statistikama najviše tuženi ginekolozi porodničari, kojih 
je $16 \%$, a slijede liječnici u hitnim službama, liječnici porodične medicine, pedijatri, internisti, kirurzi, kardiolozi, radiolozi, anesteziolozi i neurolozi. Svaka treća sudska tužba završi se povoljno za pacijenta". 
Sulejman Kendic, PhD, Specialty: Obstetrics and Gynecology ${ }^{14}$

Adem Salihagic, PhD, Specialty: Oral surgery ${ }^{15}$

\section{MEDICAL ERRORS - DEFINITION, CAUSES AND LIABILITY OF DOCTORS}

\section{Abstract}

Subject of medical / health activities is the preservation and protection of life and health improvement of individuals and society as fundamental values. Medical profession as a life direction must be devoted to the protection of human health, to the respect of human life, human values and dignity, the well-being of the patient should always be in its spotlight, it should consciously take responsibility for the patient, and that assistance must always be provided equitably and according to conscience.

Damages incurred during medical procedures appear to be particularly important and the question of liability is particularly sensitive. The medical profession, in addition to being governed by the rules of the profession, was always governed by ethical standards and only marginally by legal rules. The doctor-patient relationship was more regulated by moral than legal standards until the middle of the twentieth century, while today the situation has significantly changed.

Medicine as a science and as a practice is experiencing a rapid scientific and technological progress. The number of interventions and health services is increasing. User requirements are more complex, interventions are more offensive, with inclusion of a number of different experts in the system of protection which leads to far greater possibility of error and harm to the patient.

Keywords: medical errors, technical errors, complications, slip.

\footnotetext{
${ }^{14}$ High Medical School in Bihac.

15 Pedagogical Faculty in Bihac - Department of Sport.
} 
الأستاذ الدكتور سليمان كينديتش 17، الأستاذ الدكتور آدم صالح آغيتش أخطاء الأطباء - التعريف والأسباب ومسوؤلية الأطباء

\section{الخلاصية}

موضوع الطب هو حفظ الحياة ورعايتها وتحسين صحة الفرد والمجتمع باعتبارهما قيماً أساسية. يطلب من مهنة الطب أن تتمسك بمطلب رعاية صححة الإنسان باعتباره

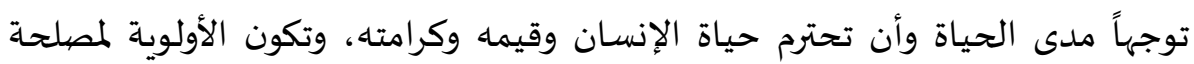

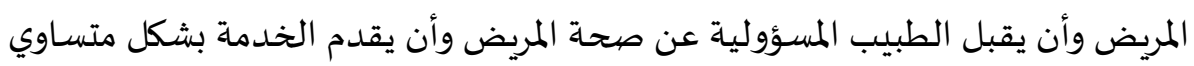
للجميع وبناء على ما يمليه ضيميره. الأضرار التي تنتج عن مزاولة هذه المهنة تعتبر مهيمة فيره بشكل خاص وموضوع

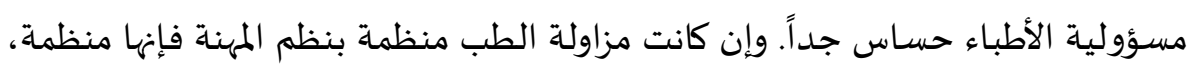

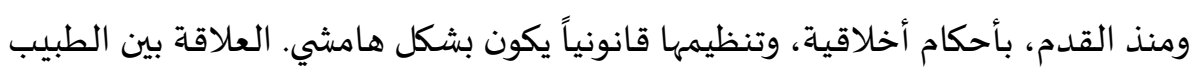

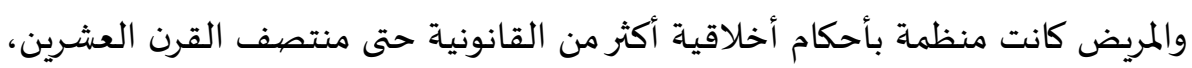
وقد اختلف ذلك اليوم بشكل ملحوظ. يشهد الطب تطوراً علمياً وتقنياً سريعاً بشقيه العلهي والتطبيقي، ويزداد عدد التود

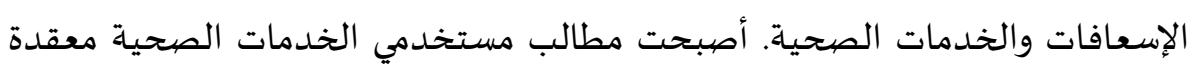

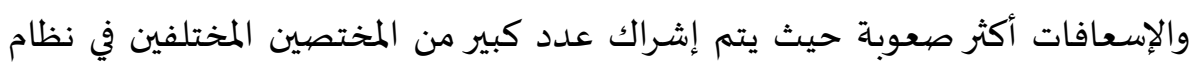
الرعاية الصحية، وبذلك يزداد احتمال حدوث الأخطاء وإلحاق الأضرار بالمرضى.

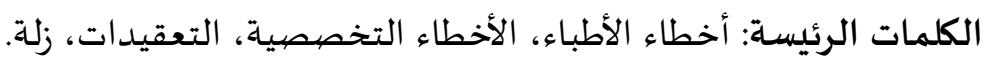

17 المعهد العالي للصحة بجامعة بهاتش.

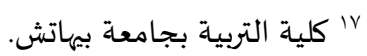

